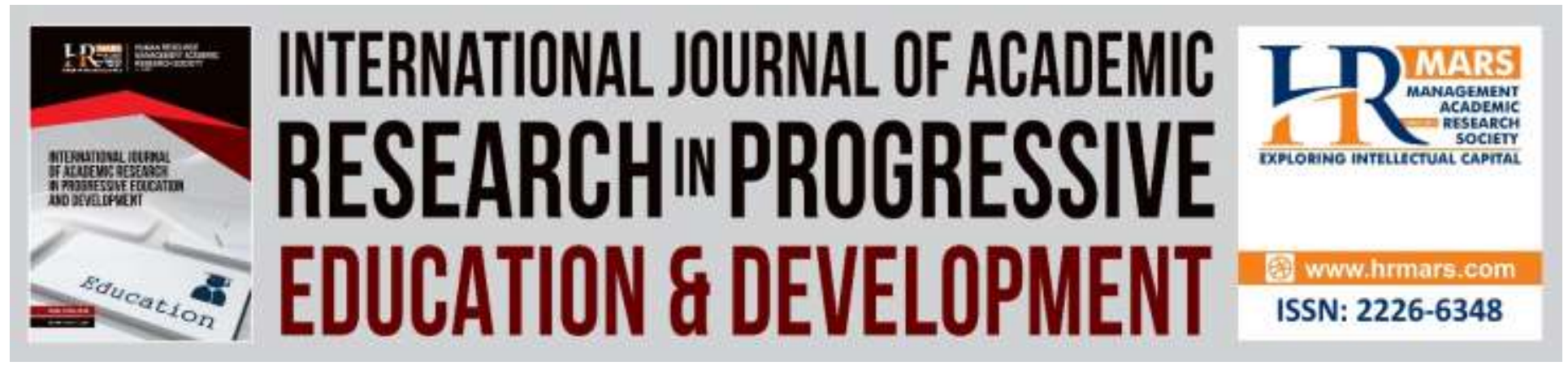

\title{
Improving Literacy Skill among Remedial Children using Literacy Module
}

\section{Vanesri Kasi, Noor Aini Ahmad, Anbarasan Sundram}

To Link this Article: http://dx.doi.org/10.6007/IJARPED/v9-i2/7298

DOI:10.6007/IJARPED/v9-i2/7298

Received: 15 March 2020, Revised: 30 April 2020, Accepted: 11 May 2020

Published Online: 10 June 2020

In-Text Citation: (Kasi et al., 2020)

To Cite this Article: Kasi, V., Ahmad, N. A., \& Sundram, A. (2020). Improving Literacy Skill among Remedial Children using Literacy Module. International Journal of Academic Research in Progressive Education and Development, 9(2), 250-258.

Copyright: (C) 2020 The Author(s)

Published by Human Resource Management Academic Research Society (www.hrmars.com)

This article is published under the Creative Commons Attribution (CC BY 4.0) license. Anyone may reproduce, distribute, translate and create derivative works of this article (for both commercial and non-commercial purposes), subject to full attribution to the original publication and authors. The full terms of this license may be seen

at: http://creativecommons.org/licences/by/4.0/legalcode

Vol. 9 (2) 2020, Pg. 250 - 258

http://hrmars.com/index.php/pages/detail/IJARPED

JOURNAL HOMEPAGE

Full Terms \& Conditions of access and use can be found at http://hrmars.com/index.php/pages/detail/publication-ethics 


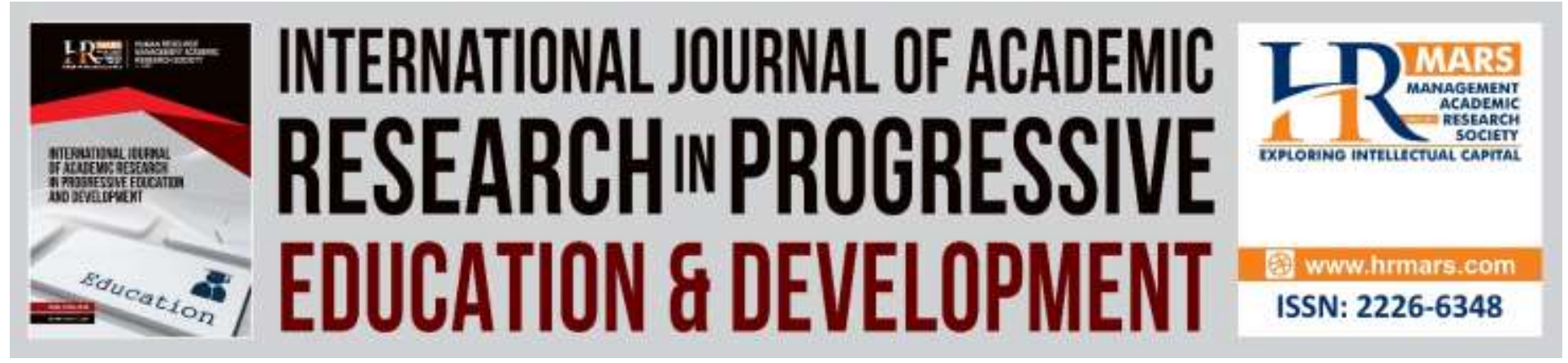

\title{
Improving Literacy Skill among Remedial Children using Literacy Module
}

\author{
Vanesri Kasi, Noor Aini Ahmad \\ Department of Special Education, Faculty of Human Development, Universiti Pendidikan Sultan \\ Idris, 35900 Tanjong Malim, Perak, Malaysia.
}

Anbarasan Sundram

Department of Curriculum Instruction, Faculty of Education, University Utara Malaysia, Sintok 06010, Bukit Kayu Hitam, Kedah.

\begin{abstract}
Literacy skills is one of the basic skills for every pupil who learns language. It had become a challenging task for pupils when they still unable to master the skill even in age of nine years old. This study aimed to develop and evaluate the impact of Literacy module on literacy problem among remedial students. Development of the module was based on adaptation of Pyramid Approach and Skinner's Verbal behavior theory. The study also analyses the effect of the module towards students' achievement in communication skill, reading skill, writing skill.-The Literacy module designed to improve literacy skills among remedial children. Based on the conceptual framework, two phases in this study are Module Development Phase and Module Evaluation Phase. During the first phase, Literacy module is developed based on Dr Sidek module development model .This study is quasi-experimental design in nature. Hence, the researcher will divide the pupils into control group and experimental group. The experimental group will be undergone teaching and learning using Literacy module. After the implementation of the module, the pupils are expected to master in literacy skills.
\end{abstract}

Keywords: Literacy Skills, Remedial.

\section{Introduction}

Literacy skill development is regarded as a noticeable milestone in the early stage classes in schools (Kern \& Friedman, 2008). Although reading is formally introduced and cultivated in the primary schools, some children begin to read before starting school, while others confront remarkable difficulties in the process of learning to read throughout primary school. This, in turn, will have negative effects on their desirable outcomes (Senechal \& LeFevre, 2002). Becoming proficient readers in classrooms is a significant issue in education. Reading programs which include particular skills that highly predict early reading success are seen to be efficient in 
generating readers'competence (Ehri et al., 2014). Improving literacy skill is one of these reading programs and it is considered as a critical prerequisite for proficiency in reading skill since it helps originate the development of word-recognition.

This, in turns, supports reading comprehension (Al Otaiba, Kosanovich \& Torgesen, 2012). The critical role of phonological awareness in the early stages of learning to read provides a considerable prognosis in which it widely and powerfully predicts and identifies children who are at risk of reading problems in the early years of schools (Ehri, 2014). The term literacy skill is used to demonstrate different levels of metalinguistic skill regarding letter (grapheme)-sound (phoneme) association (Lane, Pullen, Eisele, \& Jordan, 2002). It is important to indicate that in few studies dealt with the issue of phonological awareness and the phonemic segmentation in particular.

\section{Conceptual Frame work}

The verbal behavior intervention works on developing literacy skills. Learning across the operant also includes working on gross and fine motor imitation, textual (writing) and listening (following instructions) skills. Verbal behavior programming is also guided by the principles of Applied Behavior Analysis ( $A B A$ ) and is considered a more contemporary behavior approach. In addition to using ABA principles, a verbal behavior practitioner also incorporates B.F. Skinner's Analysis of verbal behavior. Furthermore, Sundberg and Partington (1998) have outlined and studied the Verbal behavior approach.

Verbal behavior is defined as behavior that is mediated by the behavior of another person. This means it is what we do in most of our interactions with other people. Verbal behavior is communication Lorah, (2019). It focuses attention on the functional analysis of language: looking at the conditions under which a person will use language. Rather than the communicative functions referred to by a speech-language pathologist, verbal behavior uses terms such as mands (requests), tacts (labels) or intra verbal (answering questions and responding to another). All functions of a word are taught.

Verbal behavior includes many different modalities, including speaking, using gestures, use of sign language, use of picture systems, and the use of various augmentative communication devices. Although all these modalities can be used with verbal behavior, the preferred alternative modality to speaking is signing, which is topographically similar to speaking. Verbal behavior involves teaching many skills within intensive teaching sessions using errorless teaching and fast paced instruction. In order to reduce problem behavior and enhance generalizations, tasks are presented one after another from many skill areas.

Picture Exchange Communication System (PECS) begins with teaching single word requests by means of exchanging a picture for an object, then moves on to building sentence structure. Like Milieu teaching approaches, PECS incorporates child initiation of communicative acts, by requiring the child to initiate an exchange by handing a picture to an adult in order to obtain the desired object. Direct verbal prompts such as [ what do you want? ] are avoided to help increase the spontaneity of requests. Once a powerful reinforce is identified, the child is required to exchange a picture card with the trainer for the desired item. It is recommended that two trainers be used, with one guiding the child through the picture exchange when children 
reaches towards the reinforcer. Spontaneity and generalization of the picture exchanges are addressed by; (1) gradually increasing the distance between the child and the pictures; (2) using the system in different environments; (3) involving a variety of people; (4) focusing on different reinforcers. Thus, in term of develop literacy module towards remedial children's literacy skill the conceptual framework in figure 1.1 created.

The purpose of this study is to develop and evaluate the effectiveness of Literacy module for remedial children to enhance literacy skill. Based on the purpose of the study, this research employs a quasi-experimental design. There are two groups taken as the investigated groups in this research, which are control group and experimental group.

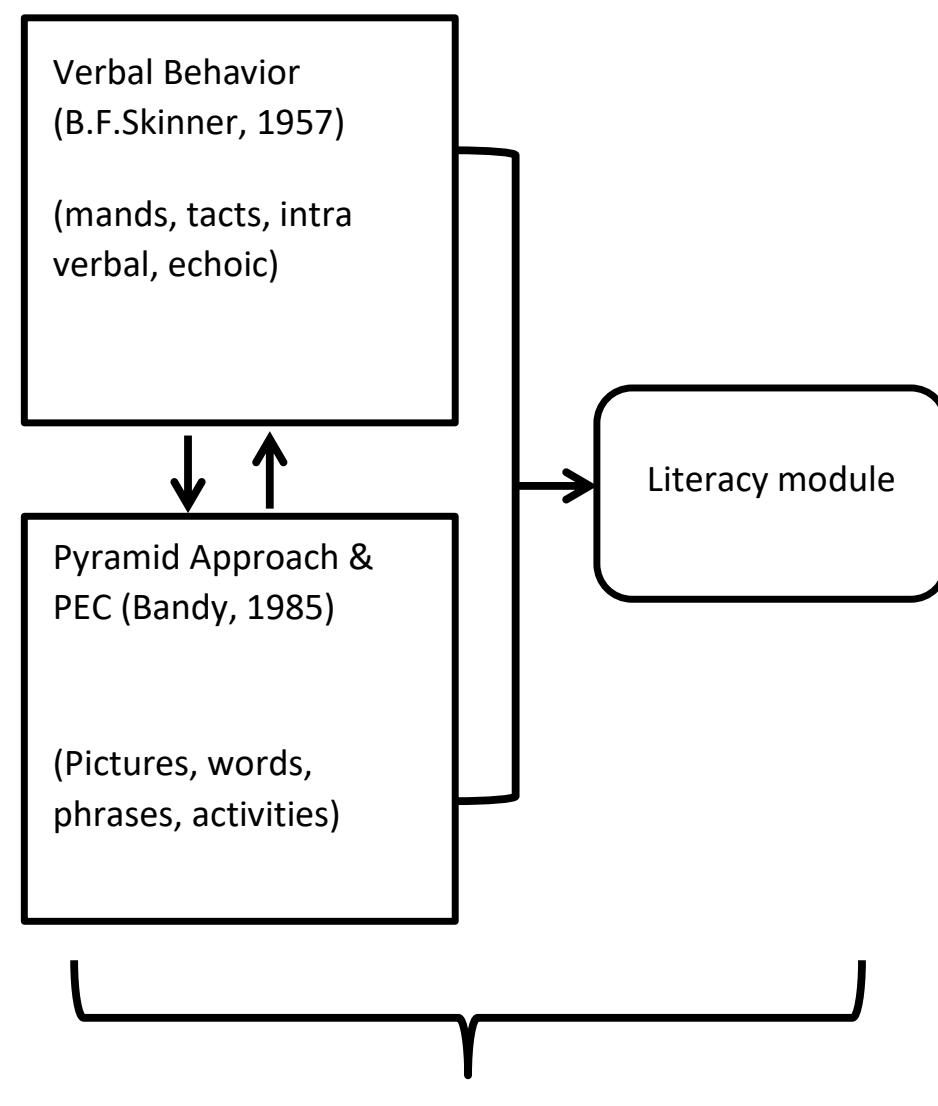

Figure 1.1 Conceptual Framework

Phase 1: Development

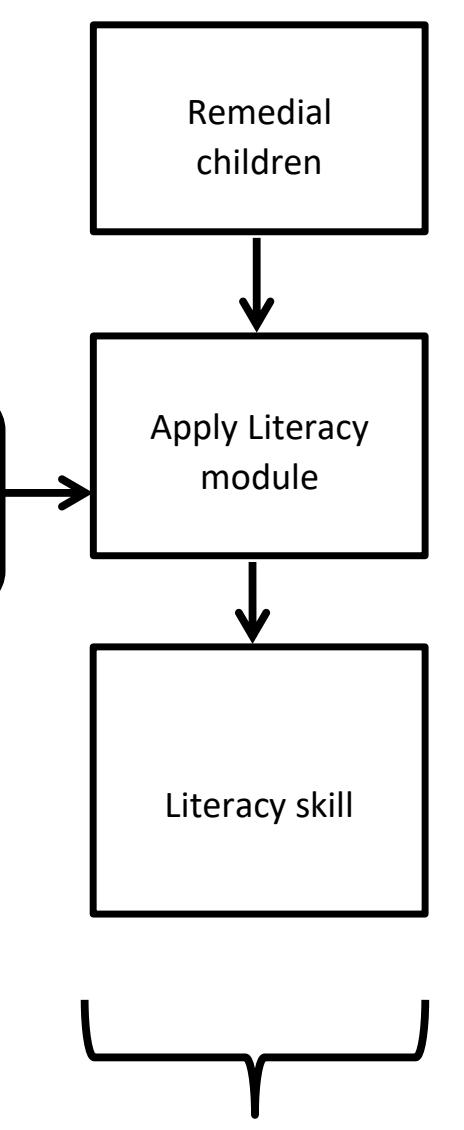

Phase 2: Evaluation

\section{Research Design}

Research design is a plan that guides the researcher in the process of collecting, analyzing, and interpreting data. A researcher needs to control factors that may contribute to the changes to prove that a treatment causes some positive effects or changes to a particular group of pupils. This study is quantitative research using the survey approach, validity and reliability of the module and quasi experimental. Roughly there are two main phases that are module construction and module evaluation phase. The module construction phase involves the analysis of literature review, review of teaching problems and module requirements, and assessment of 
Vol. 9, No. 2, 2020, E-ISSN: 2226-6348@ 2020 HRMARS

validity and reliability of modules. While the module testing phase involves an quasi experimental study approach to evaluate the level of learning change after taking part in teaching and learning of literacy skill.

The literature review and survey was conducted to build and list out of teaching problems and modules requirements, and validity and reliability of modules. This analysis is important in particular to enable review of module problems and assessments. The word review aim to list the functioning words according to the priority or importance of a word based on the viewpoint of a remedial teacher. While the validity and reliability of the modules are carried out to evaluate the modules that are constructed. The validity and reliability of this module involves the assessment of experts from the field of remedial and English literacy. While the quasi experimental method aims to evaluate the level of learning change among remedial students in teaching and learning session. The selected quasi experimental design is based on pre-test-posttest.

Table 1.1 shows the model of quasi-experimental design to evaluate the effectiveness of Literacy module in teaching literacy for remedial students. The first phase of the methodology involved understanding the research scope and objectives. Data will collect to gain more information regarding the main issue of the research, which was remedial children and the facilitator module for literacy skill. The remedial students will go through a pre-test, then a treatment for the experimental group, whereas normal teaching method for the control group. At the end, both groups will go through a post-test. The purpose of pre-test is to ensure the two groups are same before the intervention is taking place. In addition, the researcher will compare the results between pre-test and post-test to determine the changes that occur in a group. If the intervention is effective, then there will be a significant difference in the post-test results between the control group and experimental group. The treatment in this study is Literacy module to facilitate remedial children. The researcher designs this module for the experimental group. The control group will go through the normal routine traditional teaching method.

Table 1.1

Quasi-Experimental Design

\begin{tabular}{lclc}
\hline \multicolumn{1}{c}{ Group } & Pre-test & Teaching Method & Post-test \\
\hline Experimental Group & T1 & Literacy Module & T2 \\
Control Group & T1 & Traditional & T2 \\
\hline
\end{tabular}

The treatment will be running for three months period. This study implementing three months period intervention because it is an appropriate time period for the literacy skill to be taught according to the yearly teaching plan requirement. The independent variable in this study 
is the teaching of literacy skills using Literacy module and the dependent variables are the remedial children's achievement.

Figure 1.2 shows the flow chart of the research process in this study. The researcher will enroll the remedial student who have difficulties in literacy skill. The selection will be made by the teacher. Subsequently, the remedial children will go through a pre-test to select those who have serious problem in literacy skills as the participants in this study. Then, the researcher will analyse the data from the pre-test and divide the remedial children into two equivalent groups, which are experimental group and control group.

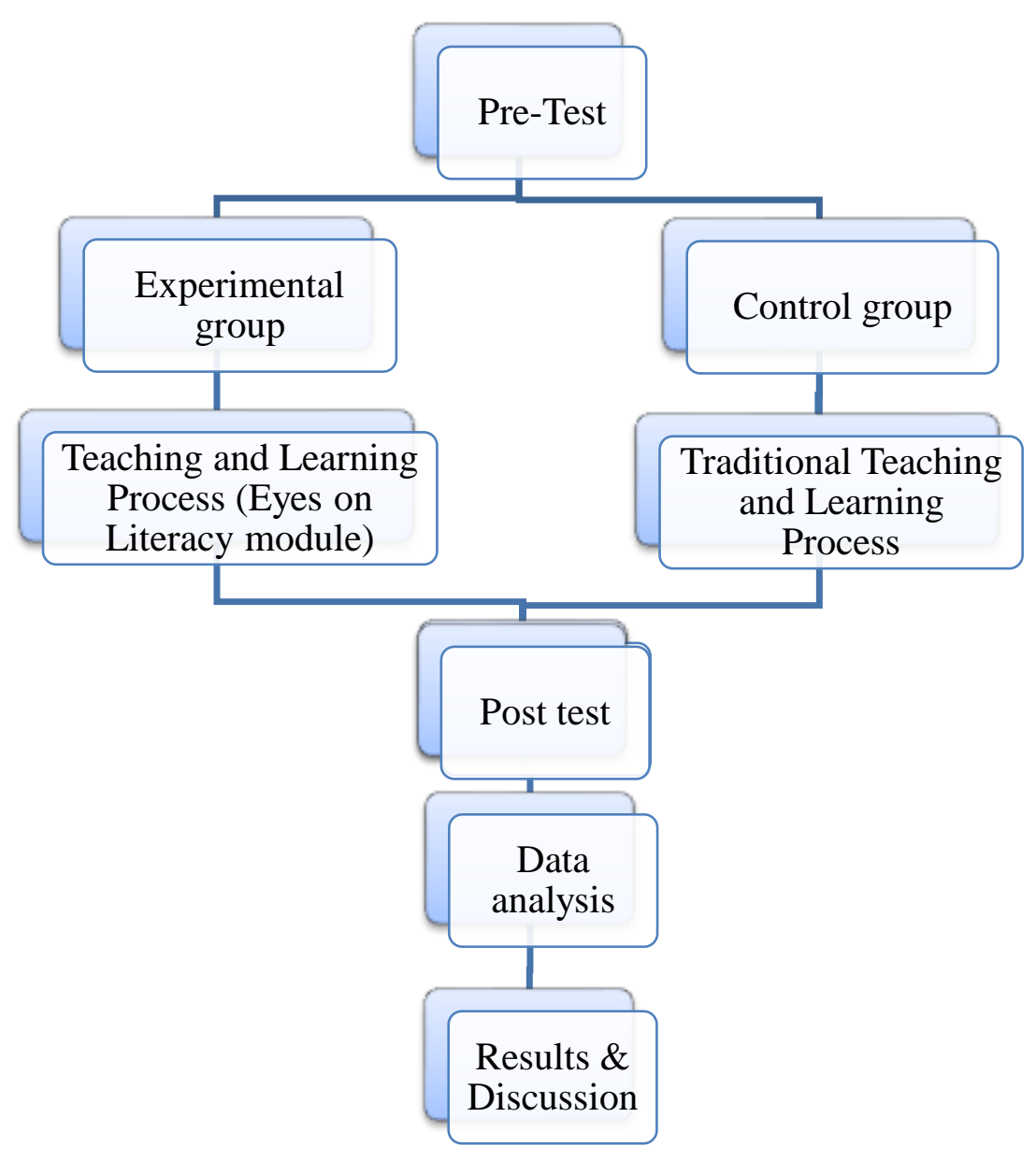

Figure 1.2 Flow Chart of Research Process

Both groups will be having teaching and learning lessons on literacy skills. The experimental group will be undergone the teaching and learning process using Literacy module as the intervention, whereas the control group will be having teaching and learning process using the traditional method. After intervention, both groups will be having a Post-Test to evaluate the effectiveness of Literacy module in teaching and learning literacy skills. The purpose of the post test is to compare the achievement of control and experimental group. The researcher will also compare the results between pre-test and post-test to determine the achievement in control and 
experimental groups. After the data analysis, the researcher will continue with the results and discussion to decide whether the application is able to improve the achievement of remedial children in literacy skill.

\section{Samples}

The sample of this study regarding the quantitative instruments is considered a convenience sample (Creswell, 2014; Fraenkel \& Wallen, 2009) since the researcher gets the permission of the principal and can obtain consent from the students (Creswell, 2012) to participate in this research. According to Farrokhi and Hamidabad (2012), a convenience sample is the most common type of sample used in studies. Samples in this study are remedial teachers and students from Muar district in year 2018. Since sample of the study is smaller than the population, the study only uses schools from Muar. 50 remedial teachers will take part in the questionnaire method. Three schools labelled as /a/, /b/ and /c/ is play role as control group and another three schools which labelled as $/ x /, / y /$ and $/ z /$ will play role as experimental group. Therefore, the total number of the sample in this study is 41 samples. Table 1.2 shows the number of samples in control and experimental group.

Table 1.2

Number of Samples in Control and Experimental Groups

\begin{tabular}{lllc}
\hline Control group & $\begin{array}{l}\text { Samples } \\
(\mathbf{N})\end{array}$ & Experimental Group & $\begin{array}{c}\text { Samples } \\
\text { (N) }\end{array}$ \\
\hline Remedial students & 20 & Remedial students & 21 \\
Total & 20 & Total & 21 \\
\hline
\end{tabular}

The researcher chooses six schools from Muar because there are pupils who share the criteria as the participants according to the specific purpose of research. The criteria of choosing the sample are: (1) remedial children, (2) children with seven to nine years old, and (3) children have difficulty with literacy skill. Hence, the sampling method in this study is purposive sampling. Purposive sampling is the most suitable sampling technique when a researcher intends to select the most typical samples to represent a population. The selected samples will undergo pre-test and post-test on word recognition in literacy skill to achieve the research objectives and research question identified.

\section{Finding and Discussion}

The comparison between scores in both pre-tests and post-tests demonstrated that experimental group has made a significant progress after the explicit instruction on literacy skill through the incorporation of the literacy module.

It was evident that significant improvements were found in the experimental group after explicit literacy skill through the use of the literacy module in class. The literacy module has 
Vol. 9, No. 2, 2020, E-ISSN: 2226-6348@ 2020 HRMARS

significantly assisted remedial children of the experimental group; they did better in the literacy skill test than those of the control group who received the instruction via a traditional method. It is important to indicate that the mean score of the experimental group was still relatively low (6.24/15). Once again, this provides further support to Brown and Haynes (1985), Ryan and Meara (1991), and Fender (2003). Nonetheless, this finding shows a remarkable development in the group's word recognition ability. This becomes clearer when the experimental group results in both pre and post word recognition tests were compared.

Table 1.3

Independent Sample T-Test Results of Post Word Recognition Tests of the Two Groups

\begin{tabular}{lccccc}
\hline Group & $\mathbf{N}$ & Mean & SD & $\mathbf{t}$ & $\mathbf{p}$ \\
\hline Experimental & 21 & 6.24 & 4.76 & & .014 \\
Control & 20 & 3.00 & 3.00 & & \\
\hline
\end{tabular}

It is interesting to note that the control group showed significant improvements after the three months literacy module instruction. This progress can be attributed to literacy module implementation. Although the mean score (2.25/15) of the control group is very low, it indicates that there is little development in the group's word recognition as shown in Table 1.3. The significant result was examined by the paired sample t-test of the control group of the students' pre- and post-word recognition tests $(t=-3.68, p<.05)$.

\section{Conclusion}

Based on Table 1.3, the results indicated that there was significant difference between the experimental and the control groups in the post word recognition test $(t=2.58, p<.05)$. The mean score of the experimental group was better than the control group. The use of literacy module that has resulted in the improvements of the experimental group students regarding the literacy skill test was positively confirmed. The literacy module therefore efficiently helped in improving students' skills in the literacy skill. It led to their better performance in the word recognition test as well.

\section{Corresponding Author}

Vanesri Kasi

Department of Special Education

Faculty of Human Development

Universiti Pendidikan Sultan Idris

35900 Tanjong Malim, Perak, Malaysia.

\section{References}

Al Otaiba, S., Kosanovich, M. L., \& Torgesen, J. K. (2012). Assessment and instruction in phonemic awareness and word recognition skills. In A. G. Kamhi \& H. W. Catts (Eds.), 
INTERNATIONAL JOURNAL OF ACADEMIC RESEARCH IN PROGRESSIVE EDUCATION AND

DEVELOPMENT

Vol. 9, No. 2, 2020, E-ISSN: 2226-6348 @ 2020 HRMARS

Language and reading disabilities (3rd ed., pp. 112-145). Upper Saddle River, NJ: Pearson Education Inc.

Brown, T. L., \& Haynes, M. (1985). Literacy background and reading development in a second language. New Directions for Child and Adolescent Development, 1985(27), 19-34.

Creswell, J. (2012). Educational research: Planning, conducting, and evaluating quantitative and qualitative research (4th ed.). Boston, MA: Pearson.

Creswell, J. (2014).Research Design: Qualitative, Quantitative, and Mixed Methods Approaches (4th ed.) Thousand Oaks, CA: Sage Publications.

Ehri, L. C. (2014) Orthographic mapping in the acquisition of sight word reading, spelling memory, and vocabulary learning. Scientific Studies of Reading, 18(1), 5-21.

Farrokhi, F., \& Hamidabad, A. (2012). Rethinking convenience sampling: Defining quality criteria. Theory and practice in language studies, 2(4), 784-792.

Fender, M. (2003). English word recognition and word integration skills of native Arabic and Japanese- speaking learners of English as a second language. Applied Psycholinguistics, 24(2), 289-315.

Fraenkel, J. R., \& Wallen, N. E. (2009). How to design and evaluate research in education, 7th ed. New York, NY: McGraw Hill.

Kern, M. L., \& Friedman, H. S. (2008). Early educational milestones as predictors of lifelong academic achievement, midlife adjustment, and longevity. Journal of Applied Developmental Psychology, 30(4), 419-430.

King, a. M., Thomeczek, M., Voreis, G., \& Scott, V. (2013). iPad(R) use in children and young adults with Autism Spectrum Disorder: An observational study. Child Language Teaching and Therapy, 30(2), 159-173.

Lane, H. B., Pullen, P. C., Eisele, M. R., \& Jordan, L. (2002). Preventing reading failure: Phonological awareness assessment and instruction. Preventing School Failure, 46(3), 101110.

Lorah, E. R., Tincani, M., \& Parnell, A. (2019). Verbal behavior intervention in autism spectrum disorders. In S. G. Little \& A. Akin-Little (Eds.), Applying psychology in the schools book series. Behavioral interventions in schools: Evidence-based positive strategies (p. 263-284). American Psychological Association.

Ryan, A., \& Meara, P. (1991). The case of the invisible vowels: Arabic speakers reading English words. Reading in a foreign language, 7(2), 531-540.

Senechal, M., \& LeFevre, J. (2002). Parental involvement in the development of children's reading skills: A five year longitudinal study. Child Development, 73(2), 445-460.

Snow, C. E., Burns, M. S., \& Griffin P. (1998). Predictors of success and failure in reading. In Committee on the Prevention of Reading Difficulties in Young Children, the Commission on Behavioral and Social Sciences and Education, \& the National Research Council (Eds.) Preventing reading difficulties in young children (pp. 100-134). Washington, DC: National Academy Press.

Sundberg, M. L., \& Partington, J. W. (1998). Teaching Language to Children with Autism or Other Developmental Disabilities. Danville, CA: Behavior Analysts, Inc. 